\title{
Protected areas and population development in the Alps
}

\author{
Oliver Bender, Charlotte E. Roth \& Hubert Job
}

Keywords: amenity migration, national parks, population, protected areas, regional development

\section{Abstract}

Nearly a quarter of the Alpine area is covered by a dense network of large protected areas (LPAs) of the four categories national park (NP), biosphere reserve (BR), nature park and world natural heritage site (WNHS). From the time of early industrialization, the Alpine area has undergone a mixed and increasingly polarized demographic development between the poles of immigration and emigration. This article investigates the possible mutual impact of population development and the existence of LPAs. The research design includes a quantitative survey of all Alpine LPAs in terms of their population development and the structure of immigration in the first decade of the $21^{\text {st }}$ century. This will be linked with qualitative expert interviews in four selected NPs. The overall results allow an interpretation of the statistical correlations between type of LPA and migration.

\section{Introduction}

Without humans there would be no LPAs (for the definition see Box 1), as they are normative frames. In former times it was often the protection of hunts that was used as an argument for a designation, today it is the maintenance of natural heritage. These kinds of conservation efforts are usually thought to have started in 1872 with the creation of Yellowstone NP. One of several explanations is the threatened disappearance of the Wild West from the unstoppable progress of settlers (Job et al. 2013). A similar situation exists today in many developing countries. More people need more resources: infrastructure, on the one hand and land, on the other, to produce energy and raw materials, food, etc. (Lama \& Job 2014; Becken \& Job 2014). The Alps are no exception - infrastructure here includes cable cars and pistes for (winter)tourism, dams for hydro-electric power generation and pumped storage facilities (Job 2005; Bender 2012; Job et al. 2014; Hasslacher 2016; Mayer \& Mose 2016, Siegrist et al. 2016 and Depraz \& Laslaz 2016 in this issue).

On a global scale there is a controversy about whether LPAs displace people or attract them. Historically, displacement was certainly more common (Mayer \& Job 2014a): protected area policy was very hierarchical for a long time and included resettlements. More recently, there are suggestions that the advantages of LPAs, especially, where they exist, of their buffer zones with fewer restrictions and better residential quality (near-natural landscape) might attract migrants (Shafer 2015). One contributory factor could be recent LPA governance approaches, which function more bottom-up than top-down and aim to integrate the resident population (Job et al. 2013). Other contributing factors are modern regional policy initiatives, which take LPAs as engines of regional development in poorly developed rural areas through nature tourism, direct marketing of agricultural produce, etc. (Mose 2004; Conradin \& Wiesmann 2014; Egner \& Jungmeier 2014; Hammer \& Siegrist 2015; Ruoss
2016; Pütz \& Job 2016; Pütz et al. 2016 and Gabrovec et al. 2016 in this issue). They are also relevant for the Alps around the emergence of gentle tourism in the 1980s and 1990s, which happened mainly in peripheral Alpine valleys and continues to date in slightly changed framing (e.g. the development concept of the mountaineering villages (Bergsteigerdörfer) of the Austrian Alpine Club) (Krippendorf 1975; Siegrist et al. 2015).

Bätzing (2015) demonstrated how the population and its spatial distribution across the Alpine area has shifted over the last 150 years. Might winner or loser regions be influenced by the existence of LPAs or only LPAs of specific categories, e. g. national parks, the focus of our research for this paper? If so, what numbers and structural features of the population are we talking about? The current debate about the so-called new bighlanders, amenity migrants who play a national and international role within the Alpine area, reflects the shifts over time in the assessment by residents, newcomers and tourists (Perlik 2011; Bender 2012; Bender \& Kanitscheider 2012, 2013). Is there any affinity to the location of Alpine LPAs? Which types in immigrants and migration motives can be identified in these regions (Pichler-Koban \& Jungmeier 2016, Streifeneder \& Omizzolo 2016 and Schamel 2016 in this issue)? These are the research questions this paper sets out to investigate.

For the analysis we delimited the LPAs in the Alps by municipal boundary. This means we only looked at municipalities which are completely situated in the relevant park or where the formal park boundary as per law or regulation runs through the municipality. Municipalities belonging to several protected areas were counted for each LPA, which makes the sums for the LPA types larger than the sums of the municipalities.

We delimit the Alpine area using the boundary defined by the Alpine Convention's CIPRA definition. This approach seems useful for the substantive analysis, which should form the basis for applied-geographical policy advice. In contrast to the pre- and 
Box 1: (Large) protected areas in the Alps

A protected area is a clearly delimited space determined by law to serve conservation and the protection of the related ecosystem services. LPAs usually exceed 10000 ha and are managed by an institution. Each of the four LPA categories - national park (NP), biosphere reserve (BR), nature park and world natural heritage site (WNHS) - has its own objectives. These are reflected in specific tasks and legal requirements that must be met to obtain the official recognition in law by the relevant national jurisdiction (Job 2017). In the Alps there are currently 131 LPAs, covering a total of around $52036 \mathrm{~km}^{2}$ (within the Alpine Convention Area) (see Figure 2; as of 05/2016). They include:

National parks (13, total area $12714 \mathrm{~km}^{2} ; 6.6 \%$ of the Alpine Convention Area):

NPs demand the highest level of protection, with an emphasis on so-called process conservation, i.e. allowing natural dynamics to recreate a largely untouched secondary wilderness (Job et al. 2013). They are the major destinations in global nature tourism (Butzmann \& Job 2016). Ideally at least three quarters of the total area are free from any land use.

Biosphere reserves $\left(12^{1}\right.$ internationally recognized by UNESCO/total area $12292 \mathrm{~km}^{2} ; 6.4 \%$ of the Alpine Convention Area):

BRs are a protected area category initiated in 1976 by UNESCO with the aim of representing all biomes across the world. They have three functions: (1) protection to help conserve biodiversity; (2) development to establish sustainable livelihoods; (3) logistics to encourage demonstration projects, environmental education, training, research and environment monitoring.

Nature parks (102/total area $24411 \mathrm{~km}^{2} ; 12.7 \%$ of the Alpine Convention Area)

Nature parks pursue classic conservation and landscape protection while also encouraging sustainable tourism. The emphasis is on the protection of cultural landscapes and the related biotic (e.g. mountain pastures or meadow orchards) and abiotic (e.g. dry stone walls of vineyard terraces or irrigation channels) artefacts. Nature parks are a fairly soft protected area category without major restrictions for land use (Pütz \& Job 2016).

UNESCO World natural heritage sites (4/total area $2620 \mathrm{~km}^{2} ; 1.4 \%$ of the Alpine Convention Area) WNHSs deserve protection mainly for the outstanding universal cultural and/or natural significance (UNESCO 2015: 11). This protection status is based on the international World Heritage Convention of 1972. It lists assets of outstanding universal value as defined by the UNESCO committee. Currently the network includes 203 natural heritage sites.

Area overlap of the four LPA types within the Alps makes up $5200 \mathrm{~km}^{2}$, resulting in a total of $46836 \mathrm{~km}^{2}(24.4 \%)$ of the Alpine Convention Area designated as LPAs. The largest overlap is between BRs and nature parks $\left(3084 \mathrm{~km}^{2}\right)$ or NPs $\left(1061 \mathrm{~km}^{2}\right)$.

1 In fact there are currently only 11 BRs with UNESCO designation. The statistical calculations, however, were done in 2015, which meant that the Nagelfluhkette, which now has a designation as nature park, but was also a BR for a while, was included in the calculation (see http://www.umweltbundesamt.at/umweltsituation/naturschutz/sg/bios_parks/ (accessed on 31/10/16).

extra-Alpine areas, the LPAs of our study and their immediate vicinity are characterized by relatively small populations, higher average altitudes and greater relief energy, less intensive agriculture and forestry and two peak seasons in tourism (Bender et al. 2005, 2007).

Population development in the Alps - a historical synopsis

Prior to the analyses below we present a brief spatio-temporal history of the population distribution based on the series of maps by Bätzing (2015, 305ff.) and following his three-way division (see Figures 1a-c); for the more recent development (1991-2001) cf. the migration balances and data on the population structure in Mapping the Alps (Tappeiner et al. 2008).

Industrial society phase (1871-1951)

As early as $1871,91 \%$ of the Alpine population lived in municipalities situated below $1000 \mathrm{~m}$ altitude.
This means that the development potential for the population and the economy is concentrated in the Alpine valleys (Gebhard 1990). The Italian and French south-western Alps experience a severe reduction in population. In the course of industrialization, accessibility of a region becomes an important factor for its demographic development. While the main valleys present population growth with the development of the railway system, the peripheral mountain regions, for instance in Switzerland, lose many people (Egli 2014). In the Eastern Alps the population grows for the most part. The German and Austrian parts benefit particularly from links with economic centres outside the Alps (Bätzing 2015).

\section{Transition phase (1951-1981)}

The severe loss of population shifts from the south-western Alps to the whole of the Italian Southern Alps, while in the French part of the Alps a partial increase in the population sets in. Population develop- 
Box 2: Generations of LPAs within the Alpine area

The evolution of Alpine LPAs can be roughly divided into three phases.

\section{Worthless land phase (1900-1935)}

Runte's worthless land theory (1977), which must be seen in the context of US protected area history, states that NPs were predominantly designated in areas where no use of natural resources was possible. It also applies to the Alps. The highest two mountain levels are economically worthless land because of their relief and the harsh climate. This is where the first three NPs are situated. Between $70 \%$ and $80 \%$ of their area is above $2000 \mathrm{~m}$ altitude, underlining the alpine character of the areas (Job et al. 2003). They could be established because local farmers sold their land to the state or entered into long-term leases. The areas in question are high-altitude pastures, which are less favoured and marginal sites. NPs were created in the most remote and structurally weak periphery of the country, e. g. the Swiss NP (Kupper 2014).

\section{Conservation phase (1961-1989)}

There is a clear break between the first and second phases of LPA establishment. Not until the era of the economic miracle in the 1960s do environmental damages become more visible, even in the Alps. Conservation policies respond to this by designating new LPAs. In 1961 the Socialist Federal Republic of Yugoslavia, today's Slovenia, designates Triglav NP (del Negro 2009; Urbanc 2016 in this issue). A substantial expansion in 1981 gives it its current shape. The three French Alpine NPs Vanoise (1963), Ecrins (1973) and Mercantour (1979) include vast skiing areas in the form of state-implemented large-scale new towns. Some of these winter tourism destinations predate the establishment of the park and continved to grow, raising the issue of compatibility of high-tech mass tourism and conservation or landscape protection (Depraz \& Laslaz 2016 and Mayer \& Mose 2016 in this issue). Berchtesgaden NP was created on the basis of a measure to prevent the construction of a cable car up Watzmann peak to encourage winter tourism (Schumacher \& Job 2013). Today this LPA has by far the highest visitor density in the Alps with 76 people per hectare (Job et al. 2016; Schamel 2016 in this issue).

\section{Sustainable development phase (as of 1990)}

In the most recent phase a reserve boom set in, which included a relatively high number of NPs and other LPA categories (Box 1) covering large areas. In this the Alps, with a slight time lag, follow the international trend of area conservation (Becken \& Job 2014). The creation of the Alpine Convention in 1989, with the Rio Conference of 1992 and the Seville Conference in 1995 of the Man and the Biosphere Programme introduce a paradigm shift in conservation (Lange 2005). The previous understanding of conservation without human use (fences-and-fines policy) is modernized to include conservation objectives that allow an adapted form of using resources (use-it-or-loose-it policy). LPAs are no longer seen as black holes for regional development (Job 2008). Collaborative forms of management come into force, which grant more rights to stakeholders in the local municipalities of the parks. Integrative conservation boosts the status of soft forms of protection, such as nature parks (Hammer et al. 2015). This LPA category, controversial for its low protective effect, is introduced in Germany in 1957, in France in 1967, in Italy in 1971, in Austria in 1979 and in Switzerland in 2008. Greater numbers of nature parks in the Alps only come in within the last 25 years (Pütz \& Job 2016; see Figure 2 and Pütz et al. 2016 in this issue).

ment happens not so much on a large spatial scale but more differentiated across smaller spatial scales. One main reason is the emergence of economic disparities in the Alps in the wake of road construction. Industrial municipalities develop along the main transport routes. Better accessibility of rural areas also encourages mass tourism in the tourist centres (Bätzing \& Perlik 1995).

\section{Service society phase (1981-2011)}

For the first time the growth rate of the Alpine population exceeds the European average (Bätzing 2015), with the most sustained increase in the German Alps (Mayer \& Job 2014b). Interlinking and improved acces- sibility of Alpine towns and especially those along the Alpine rim lead to the development of agglomerations with more population growth. Soft location factors become more important and suburbanization progresses. Multi-local living manifests itself in many areas, first as touristic second homes used more or less regularly (cf. Sonderegger 2014); more recent forms, such as retirement and amenity migration, may be multi-local or turn into a permanent shift of residence (Bender \& Borsdorf 2014; Borsdorf 2014). After the French Alps, a partial trend reversal reaches the Italian Alps and the population grows again (Steinicke et al. 2012). The Austrian Eastern Alps suffer from deindustrialization and shrinking population. Tourism continues to be 
Table 1 - Population structure, migration balance and in-migration structure by type of LPA and in four selected Alpine NPs. $L P A$ - large protected areas; BR - biosphere reserves; WNHS - world natural heritage site; NP - national park; SNP - Swiss National Park; StNP - Stelvio National Park; HTNP - Hohe Tauern National Park; BNP - Berchtesgaden National Park.

\begin{tabular}{|c|c|c|c|c|c|c|c|c|c|c|}
\hline Total & $\begin{array}{l}\text { All Alpine } \\
\text { municipalities }\end{array}$ & no LPA & $\begin{array}{l}\begin{array}{l}\text { Nature } \\
\text { park }\end{array} \\
\end{array}$ & BR & WNHS & NP & SNP & StNP & HTNP & BNP \\
\hline Pop. 2001 (FR: 1999; SI: 2008) & 13345311 & 10852016 & 1647337 & 561160 & 325530 & 412679 & 5712 & 61932 & 60518 & 14969 \\
\hline \multicolumn{11}{|l|}{ Share in $\%$ of the total population } \\
\hline women & 51.16 & 51.17 & 51.09 & 51.55 & 51.32 & 50.93 & 50.98 & 50.05 & 50.56 & 51.64 \\
\hline $0-14$ years & 16.46 & 16.48 & 16.63 & 16.57 & 15.32 & 15.86 & 16.93 & 17.68 & 19.11 & 15.35 \\
\hline $15-29$ years & 18.20 & 18.27 & 17.98 & 16.61 & 17.82 & 18.32 & 19.22 & 20.17 & 20.84 & 16.63 \\
\hline $30-49$ years & 30.53 & 30.58 & 30.38 & 29.50 & 30.34 & 30.23 & 28.78 & 31.13 & 30.91 & 29.64 \\
\hline $50-74$ years & 27.06 & 26.95 & 27.47 & 28.73 & 27.97 & 27.35 & 26.45 & 24.10 & 23.23 & 29.87 \\
\hline $75+$ years & 7.74 & 7.72 & 7.55 & 8.60 & 8.55 & 8.24 & 8.61 & 6.92 & 5.91 & 8.52 \\
\hline foreign nationals & 8.11 & 8.55 & 6.42 & 7.72 & 5.39 & 4.14 & 10.59 & 1.95 & 7.17 & nd \\
\hline \multicolumn{11}{|c|}{ Annual migration balance per 1000 residents } \\
\hline total & 6.20 & 6.31 & 5.53 & 9.08 & 4.75 & 4.46 & 7.27 & 1.35 & -5.80 & 0.73 \\
\hline vis-a-vis the NUTS2 area & 0.36 & 0.40 & 0.40 & -0.24 & -0.67 & -0.93 & 0.93 & -2.02 & -3.39 & -5.96 \\
\hline vis-a-vis the national Alpine area & 0.00 & 0.07 & -0.05 & -0.16 & -0.71 & -1.68 & 0.77 & -1.89 & -3.99 & -5.08 \\
\hline national & 1.57 & 1.42 & 2.54 & 4.84 & -0.90 & 0.30 & -3.68 & -1.70 & -5.72 & 0.07 \\
\hline international & 4.63 & 4.88 & 2.99 & 4.24 & 5.65 & 4.16 & 10.94 & 3.05 & -0.09 & 0.66 \\
\hline \multicolumn{11}{|c|}{ Annual in-migration per 1000 residents } \\
\hline total & 46.91 & 47.27 & 45.43 & 58.31 & 30.09 & 37.82 & 33.79 & 20.34 & 33.40 & 75.10 \\
\hline \multicolumn{11}{|l|}{ Share in $\%$ of total in-migration } \\
\hline women & 49.98 & 49.96 & 50.06 & 50.05 & 51.85 & 50.71 & 50.93 & 51.81 & 51.67 & 50.76 \\
\hline $0-14$ years & 14.29 & 14.18 & 15.03 & 15.31 & 13.74 & 13.78 & 12.80 & 16.36 & 16.78 & 10.83 \\
\hline $15-29$ years & 32.92 & 33.10 & 32.41 & 30.65 & 27.35 & 32.54 & 22.12 & 34.02 & 40.90 & 43.83 \\
\hline $30-49$ years & 36.69 & 36.72 & 36.84 & 35.19 & 41.56 & 36.00 & 41.30 & 37.55 & 29.37 & 31.75 \\
\hline $50-74$ years & 12.93 & 12.87 & 12.72 & 14.42 & 14.46 & 13.81 & 20.98 & 9.96 & 9.23 & 12.04 \\
\hline $75+$ years & 3.18 & 3.13 & 3.00 & 4.44 & 2.89 & 3.87 & 2.80 & 2.12 & 3.72 & 1.55 \\
\hline foreign nationals & 25.92 & 26.12 & 24.64 & 22.99 & 32.08 & 23.72 & 40.21 & 31.54 & 36.34 & 32.22 \\
\hline from the NUTS2 area & 65.23 & 65.91 & 63.51 & 54.42 & 62.08 & 61.91 & 53.88 & 63.06 & 55.14 & 50.19 \\
\hline from the national Alpine area & 53.21 & 54.21 & 49.52 & 35.95 & 58.14 & 51.41 & 55.64 & 58.49 & 66.24 & 42.57 \\
\hline from abroad & 16.74 & 16.63 & 16.96 & 15.74 & 21.42 & 17.85 & 28.89 & 23.93 & 26.60 & 24.23 \\
\hline from other Alpine countries" & 4.24 & 3.99 & 4.83 & 6.33 & 4.22 & 4.98 & 10.35 & 4.89 & 8.49 & 7.19 \\
\hline from Northern and Western Europe" & 0.85 & 0.82 & 1.00 & 0.77 & 0.64 & 1.42 & 1.21 & 0.40 & 4.38 & 0.66 \\
\hline from Southern Europe* & 0.67 & 0.71 & 0.38 & 0.33 & 1.24 & 0.57 & 13.98 & 0.50 & 0.26 & 0.33 \\
\hline from Southeastern Europe" & 4.02 & 4.01 & 4.19 & 3.06 & 5.26 & 3.88 & 0.88 & 7.95 & 5.68 & 5.31 \\
\hline from Eastern Europe" & 2.20 & 2.24 & 1.76 & 2.14 & 3.69 & 2.87 & 0.88 & 5.57 & 3.21 & 8.90 \\
\hline from Africa" & 1.39 & 1.44 & 1.40 & 0.67 & 1.31 & 0.95 & 0.06 & 1.83 & 0.25 & 0.13 \\
\hline from Asia Pacific" & 1.49 & 1.55 & 1.27 & 1.02 & 1.62 & 0.97 & 0.55 & 1.21 & 1.72 & 1.09 \\
\hline from America* & 1.24 & 1.25 & 1.20 & 0.63 & 3.31 & 1.85 & 0.61 & 1.57 & 0.59 & 0.60 \\
\hline from unknown country" & 0.65 & 0.61 & 0.93 & 0.79 & 0.13 & 0.35 & 0.39 & 0.00 & 2.02 & 0.04 \\
\hline
\end{tabular}

concentrated in tourist centres, small tourist municipalities suffer losses of income and people (Bender 2012). In terms of altitude, $95 \%$ of the population now live below $1000 \mathrm{~m}$; cities, and particularly their peri-urban surroundings, continue to grow (Perlik 2011).

\section{Research design and methodological framework}

The analyses below (see Results sections) are based, first, on quantitative statistical data interpretation as desk research, using two databases created by the authors in recent years. The areas and boundaries of the LPA categories NP, BR, nature park and UNESCO WNHS across the Alpine Arc have been captured in a
GIS layer and put through a statistical analysis (www. galpis.at). It is based on the World Database on Protected Areas (WDPA; www.protectedplanet.net); missing or corrupted LPA polygons were corrected using diverse sources (official data; self-representation of the LPA, etc.). The area balances in Box 1 were derived from this new GIS layer.

The second database captures the spatial population development of Alpine municipalities in the first decade of the $21^{\text {st }}$ century. The relevant raw data were obtained from the national statistics authorities of Germany, Austria, Italy and Slovenia via (sometimes payable) special analyses from the national resident registers. In France and Switzerland the data stem from census data. All data were then harmonized 
spatio-temporally for a contribution ${ }^{1}$ to the $5^{\text {th }}$ Report on the State of the Alps (Bender 2015). The basic data include the number of indigenous residents and that of the in-migrants (and in some cases also the outmigrants), broken down by gender, age, nationality as well as source and destination municipality / country.

Second, and complementing the quantitative research, four NPs in the Eastern Alps were studied empirically as case studies: Swiss NP, Stilfser Joch NP, Hohe Tauern NP and Berchtesgaden NP. The selection covers four Alpine states and reflects the diversity of this category in that it includes old and comparatively young, as well as larger and smaller LPAs (cf. Box 1 and 2 and Figure 1a-c).

For a closer investigation whether and, if so, how protected areas influence population development and in-migration in particular, we carried out guided expert interviews. We addressed the directors of the NPs listed above and high-ranking politicians (mayors) and administrators of the local municipalities as experts because they would have the most detailed information on our topic at hand. All NP directors and the high-ranking politicians and administrators of selected NP municipalities received a written enquiry, resulting in 15 expert interviews of 45 minutes average length in 2015 and 2016. We then applied a qualitative analysis after Mayring (2002), studying the interview material systematically using a predefined system of 25 categories linked to the research questions. In this way the relevant details were identified, structured and summarized. The analysis should reveal which framework conditions influence population development in the immediate vicinity of the NPs, identify types of migration and regional policy strategies that might be effective in these processes. The second Results section summarizes the results, Roth (2016) provides a detailed interpretation.

\section{Results of the quantitative investigation}

Indicators and types of LPAs

The first issue for the statistical analysis was finding out whether the types of LPAs differed from each other or from the unprotected part of the Alps in terms of population structure, migration balance and in-migration ${ }^{2}$. We started by operationalizing the inmigration characteristics via different indicators, then calculated these indicators for the relevant Alpine municipalities and LPAs. Table 1 summarizes the indicator values by type of LPA (versus total Alps and unprotected areas) and for the four NPs further studied using qualitative methods.

Compared with non-protected Alpine areas, LPAs have a slightly older population, a lower migration bal-

\footnotetext{
The Swiss data were not (yet) available for RSA V and we prepared and completed them specially for this paper.

2 In-migration means any shift of the main residence from one municipality to another.
}

ance and (except for BRs) less in-migration; within inmigration the share of younger people (aged 15-29) is slightly lower and that of the cohort aged 50-74 years slightly higher (except in nature parks); a slightly higher share of in-migration is from abroad.

LPA types mainly differ from each other in these respects: BRs have a considerably higher - particularly national - migration balance and a considerably higher in-migration than any other type of LPA and the non-protected areas. In BRs there is little in-migration from abroad or from national close range, i. e. largely from inland regions further away.

Nature parks present a positive migration balance with the closer region (NUTS2) and, similar to BRs, there is a roughly similar positive migration balance with both national regions and foreign countries. The emigration of young people of education and training age seems lower here.

NPs and WNHSs present the lowest migration balance - nationally even negative - and the lowest inmigration of all LPAs. In-migration of young people is comparatively low and that of older people slightly higher. Moreover, a larger share of in-migration is from abroad and there is a clearly positive migration balance with foreign countries.

\section{Statistic significance}

Another issue was the question whether the differences in certain in-migration characteristics between the types of LPAs were significant, i. e. whether there is a statistical connection between LPA status and type of in-migration. To answer this question we performed the Kruskal Wallis Test using SPSS statistics and analysis software (Kruskal \& Wallis 1952): a nonparametric test to check, within a variance analysis, if independent samples stem from a common universe in terms of variables of at least an ordinal scale. The test should reveal whether the sample, for instance, of the nature parks and their municipalities, presented the same characteristics as the samples of the other types of LPA and their municipalities, with all Alpine municipalities forming the universe. The null hypothesis $\mathrm{H}_{0}$ meant that there was no difference between the groups. If, however, the statistical probability is $\mathrm{p}$ $<5 \%$ that the compared samples would come from the same universe, the conventional assumption is that they differ (significance level 0.05).

On the first investigation level we compared the types of LPA and found no significant difference from the non-protected Alpine area as a whole or between the types of LPA. The reason for this is that the size of the recognizable difference is related to the number of LPAs in the relevant category. The fewer LPAs a category has, the greater the difference must be to register as significant.

On the second investigation level we compared the LPA municipalities by type of LPA with each other and with the rest of the Alpine area (municipalities without LPA status). 


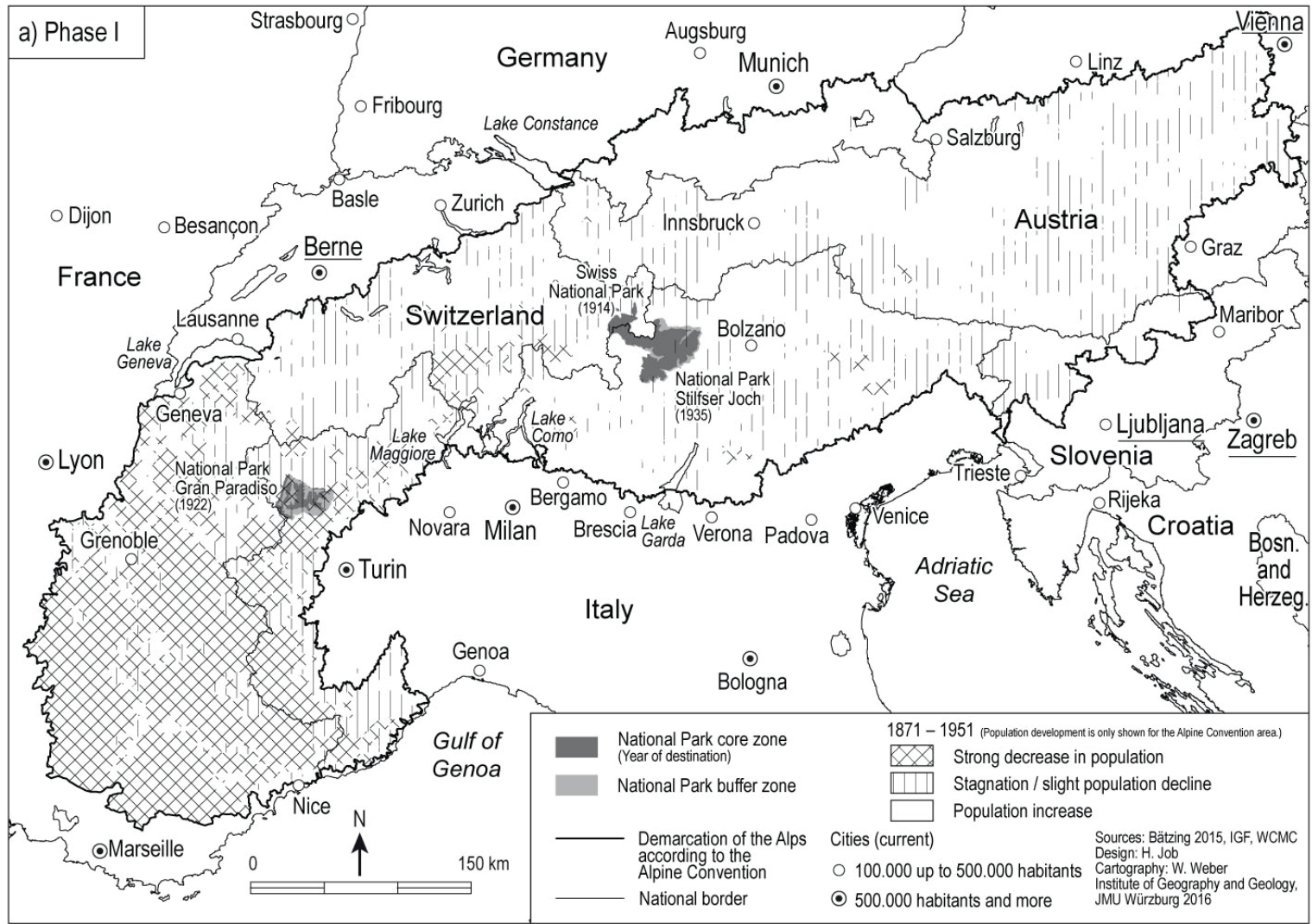

Figure 1a-Population development during the first phase of establishment of NPs within the Alps.

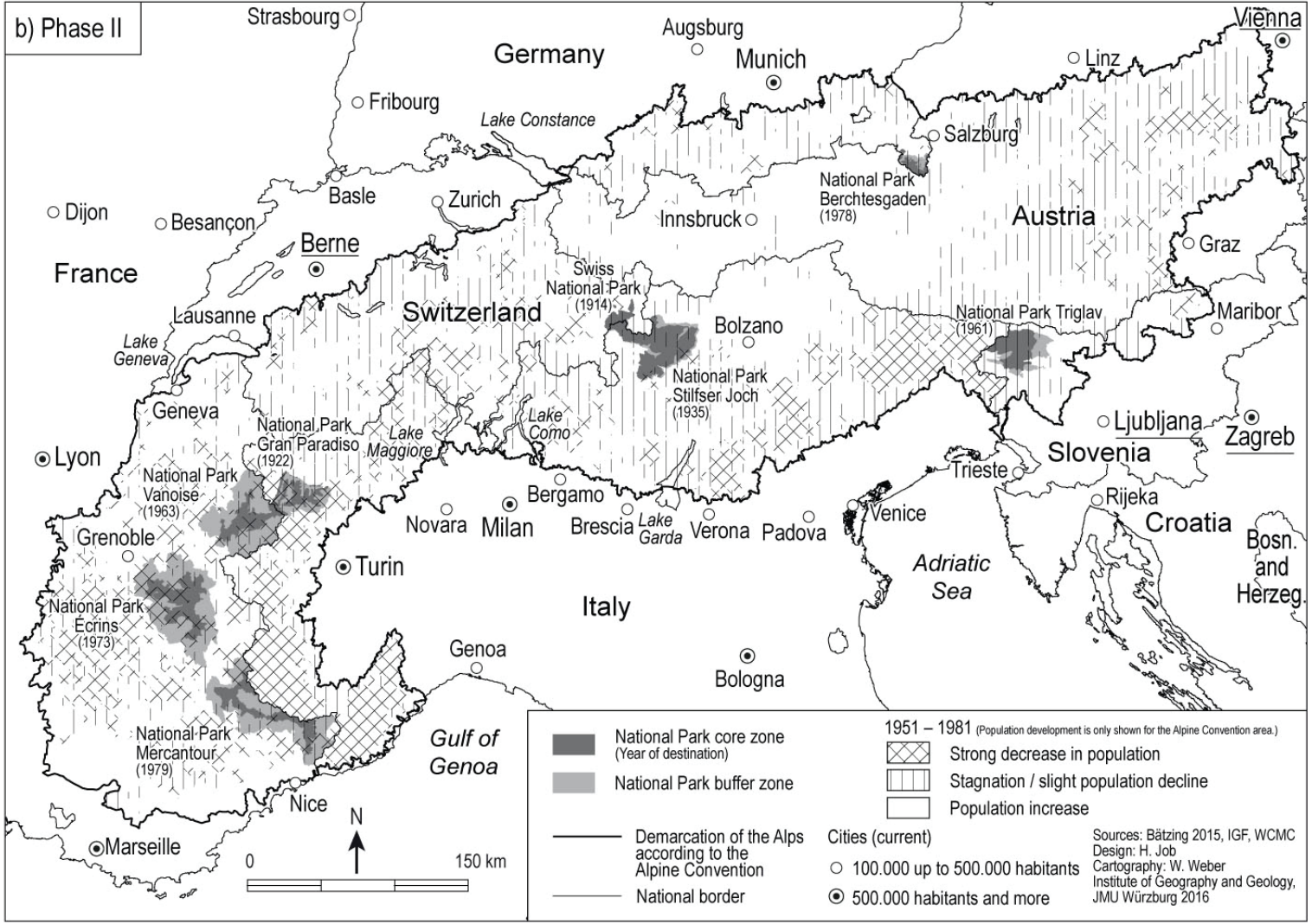

Figure 1b-Population development during the second phase of establishment of NPs within the Alps. 


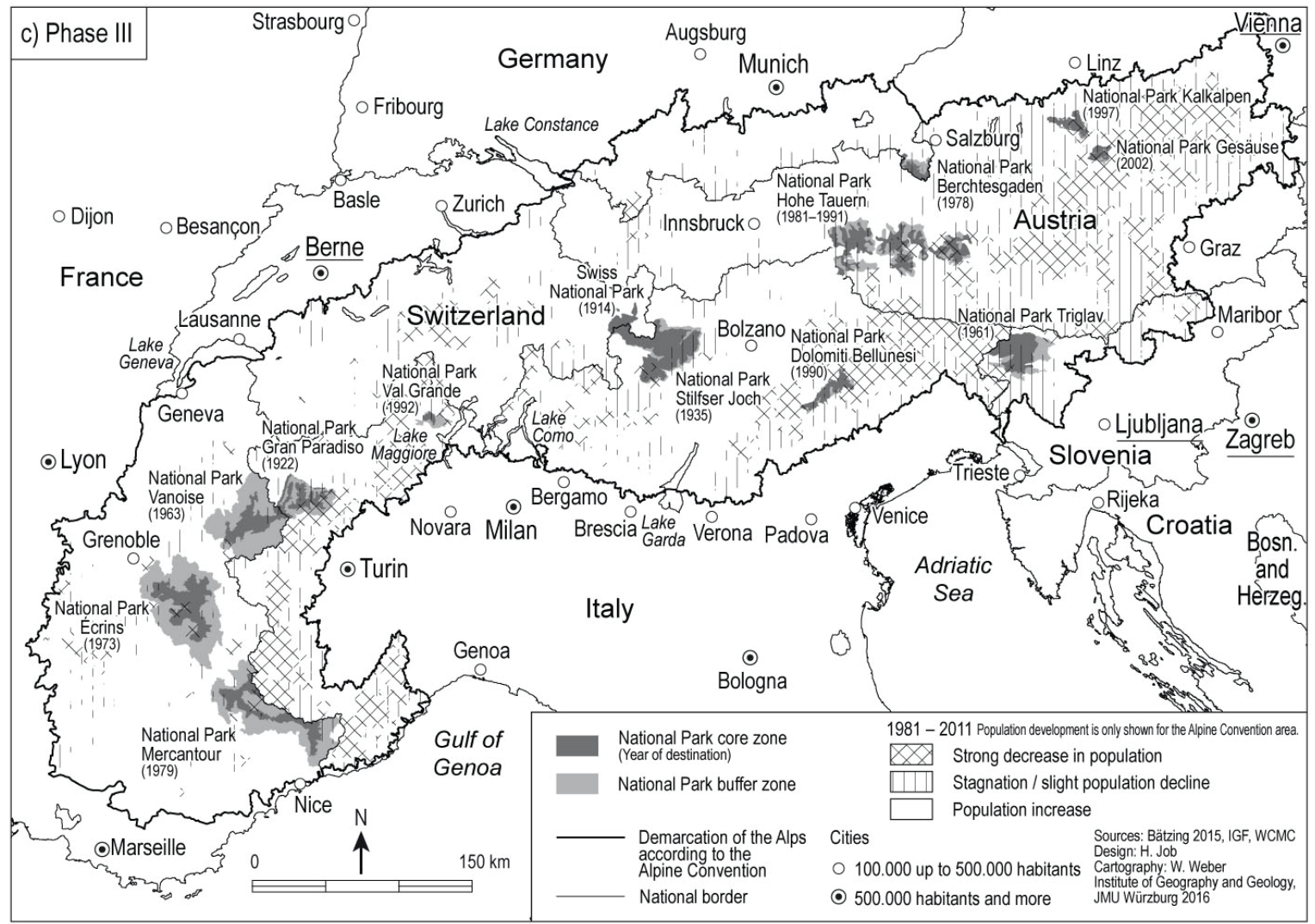

Figure 1c-Population development during the third phase of establishment of NPs within the Alps.

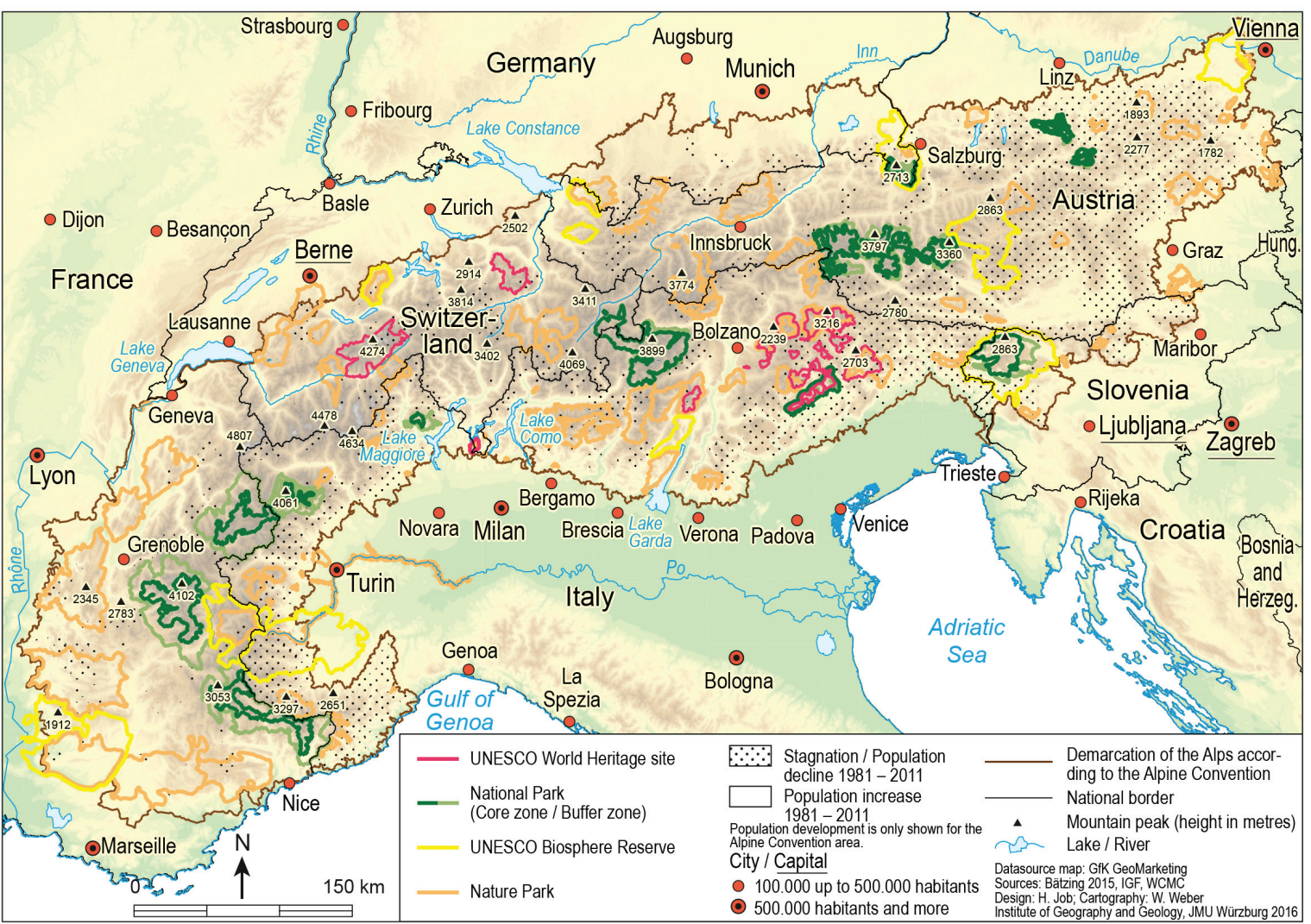

Figure 2 - Large protected areas in the Alps (as of 05/2016). 
The analysed indicators showed the following trend: WNHS differ most from the non-LPA municipalities. Within the LPA municipalities, nature parks and NPs present the least statistically significant differences. WNHS municipalities differ most from municipalities in other types of LPA, NP municipalities differ least from the others. The biggest factor in the statistically significant differences are the in-migration indicators, followed by the indicators on migration balance and population structure (for details on the indicators, see Table 1).

Another striking finding are the uneven degrees of difference between LPA types between Alpine states. This suggests that the country to which a municipality belongs influences the in-migration more than the LPA it belongs to. The special case of WNHSs (comparatively little in-migration but a high share of foreign immigrants, esp. from south-eastern and Southern Europe, strongly positive migration balance with foreign countries) which are only found in Italy and Switzerland must be seen against this background (see Bender 2015).

Characterization of the four NPs of the qualitative study (see Table 1)

In terms of population structure (2001) Hohe Tauern NP and Stelvio NP have a comparatively young, Swiss NP and Berchtesgaden NP a comparatively old population; in Berchtesgaden NP the age cohorts $<30$ years are smaller and the age cohorts $>50$ years larger than the average for all NPs. Swiss NP has a strongly positive migration balance, Stelvio NP and Berchtesgaden NP a slightly positive one (lower than the average for all NPs) and Hohe Tauern NP a strongly negative balance. In all four NPs the balance with foreign countries is significantly higher than the inland balance and strongly negative with the immediate region.

In-migrants in all four NPs predominantly come from abroad and/or are foreign nationals. Of the countries of origin Eastern Europe dominates in Berchtesgaden NP, south-eastern Europe in Stelvio NP, Southern Europe (without Italy) in Swiss NP and the other Alpine countries in Hohe Tauern NP. In age terms the in-migrants include an above average share of the cohorts 15-29 years (compared with the average of all NPs or the whole Alpine area) and a belowaverage share of the cohorts aged $50-74$ years. Swiss $\mathrm{NP}$ is an exception with very little in-migration of young and high in-migration of older people.

\section{Results of the in-depth qualitative case studies}

\section{Swiss NP}

The Swiss NP in Lower Engadin and Val Müstair has a very peripheral location within Switzerland. The NP municipalities are seen as structurally weak, small enterprises in the secondary sector, esp. in construction, and enterprises in tourism have provided too few jobs for a long time, which is why many of the younger people move away. The most recent political developments in Switzerland as a whole weaken the regional economy further: When the Swiss franc was decoupled from the euro in 2015 it made all tourist offerings more expensive, leading to a shift abroad of tourist flows; the second homes act of 2016 limits the share of second homes in a municipality to $20 \%$, unless it already had a higher share when the act came into force.

Regional experts identified the following groups of in-migrants:

1. foreign nationals who come into the region as labour migrants in tourism, construction or the health service because of the high level of pay in Switzerland;

2. employees who move into the NP region because of affordable housing prices and commute to their place of work, usually in Upper Engadin;

3. indigenous returners, who left for training or for their early career and now have found a job in their native municipality;

4. the cohorts aged 50-74 years (Swiss, some locals, plus foreign nationals), who mostly start up second homes as part of a multi-local lifestyle. In the municipality of Scuol second homes make up around $50 \%$ (2015), which might in future be turned from holiday homes into retirement residences.

Some experts suspect that the second group makes up the largest share of in-migration. However, if you look at the statistical analysis (section Hohe Tauern NP below), it seems they underestimate the cohorts aged 50-74 years, which stand predominantly for amenity-led migration.

The NP is seen as highly significant for regional tourism and with it for stabilizing the economy. $\mathrm{Mu}-$ nicipal politicians also assume that the NP is a central motif for establishing a retirement residence. Experts from the NP, however, rate the park as just one of many migration motives.

All interviewed experts support the limitation on second homes. In addition, the designation of building land is restricted in an effort to prevent further land grab.

\section{Stilfser Joch NP}

Despite its fairly peripheral location within South Tyrol, the job market in the Vinschgau region is stable or growing slightly, both in the production and the service sectors. In addition there is commuting into Merano and nearby Switzerland. Only the municipalities at higher altitudes suffer from out-migration, mainly of the young, while the municipalities in the main valley experience in-migration.

Regional experts identified the following groups of in-migrants:

1. individuals and young families who return to South Tyrol and/or the Vinschgau region in particular, 
after absences for training, once they have found a job there;

2. foreign in-migrants, mainly from the EU, esp. from Austria and Germany as labour migrants;

3. returners of retirement age;

4. in-migration of former tourists, albeit on a small scale.

Migration motives listed include the availability of jobs, family reasons, closeness to the home region and the availability of comparatively affordable housing; also leisure options and a favourable climate. The NP itself is hardly noticed as a reason for in-migration.

The moderate in-migration is welcomed by the local politicians but not encouraged, for instance, by extensive building land designations. State subsidies for renovating older buildings aim at enhancing the village / town centres and avoid the take-up of land at the expense of agriculture. There are relatively few second homes. They are partly welcome (spending power, property enhancement) and partly disliked (rise in real estate prices, high infrastructure costs).

\section{Hohe Tavern NP}

The Austrian Eastern Alps, which include Hohe Tauern NP, are discussed as a demographically problematic area (Fischer \& Pizzera 2015; Cede et al. 2014). The peripheral location of the NP at the edge of three federal states (Carinthia, Salzburg and Tyrol) means job deficits, commuting and high rates of unemployed (Getzner 2010), a strongly negative migration balance (Table 1) and ultimately a shrinking population. Only some municipalities at the edge of the area or those with highly developed tourism have a stable or growing population.

In-migration into the NP area is spatially quite selective because of the differences in municipal structure and concerns the following groups:

1. seasonal labour in tourism, mostly from Eastern European EU countries;

2. young families in search of affordable building land;

3. amenity migrants aged $50-74$ years, often using holiday homes that could be turned into retirement residences later.

The NP is seen as a pull factor for this last group. The park is also recognized as a regional actor pursuing sustainable development in cooperation with the local municipalities. The rise in second homes, which can be seen as connected to the tourist character of the area and the increasingly multi-local lifestyle of the indigenous people, is viewed critically by regional actors and the establishment of new second homes is restricted using federal state spatial planning instruments (Sonderegger \& Bätzing 2012).

\section{Berchtesgaden NP}

Despite the closeness to the larger Salzburg area (in Austria) the NP municipalities are in a peripheral loca- tion within Bavaria. The regional economy provides only few high-quality jobs; housing is expensive and in short supply. Migration balance is only very slightly positive (Table 1) and experts see in-migration as negligible.

Similar in-migration groups as in the other NPs of the study could be identified:

1. seasonal labour in tourism;

2. young families from the region;

3. cohorts aged 50-74 years from more distant German regions (and not from abroad) are attracted by the quality of the landscape and the cultural options offered by the area of the city of Salzburg.

Experts did not see amenity migration explicitly related to the existence of the NP, but identified an in-migration of former nature tourists who decided to set up a retirement residence in the NP municipalities. However, the municipalities do not explicitly want an influx of older people, rather they hope for an inmigration of families and highly qualified labour with high spending power. The lack of available building land, however, means that none of the municipalities actively encourages in-migration.

\section{Discussion and conclusion}

Our quantitative survey and the qualitative case studies reveal that population development in the Alpine area is highly heterogeneous in both spatial and temporal terms. Growing and shrinking regions are often located in close vicinity, so that it is not really possible to make statements about large-scale changes (PSAC 2015, 36). Comparative pointers to some parallel but in total also heterogeneous developments in other mountain regions can be found in Bender and Kanitscheider (2013), Borsdorf (2009), Moss (2006) and Moss et al. (2009).

Looking at the demographic development and the designation of LPAs one can at least note that the creation of the protected areas do not go along with a significant decline in population development. Rather it seems that certain, mostly younger, NPs and nature parks were designated in areas with predominant outmigration because the regional structural weaknesses exceeded the average for the relevant country. Nature tourism and near-natural landscapes with the relevant conservation label seem to have been introduced by regional policy to provide soft location factors as a solution (Hammer et al. 2015). In recent years this has also brought about increased efforts to establish BRs and WNHSs (Pütz \& Job 2016).

If you just take the quantitative survey (first Results section above) there are statistically significant correlations for Alpine municipalities between demographics and belonging to a LPA. In these municipalities the population is a bit older, in-migration a bit lower and the share of foreign in-migrants a bit higher than the Alpine average. Differences between the types of 
Alpine LPA show the following trends: In-migration gains are largest in BR municipalities, with a slightly larger proportion of inland in-migrants. In nature park municipalities there is a striking positive migration balance with the surrounding region (same NUTS2 region) - this may be due to the fact that nature parks are more often situated on the Alpine rim than other LPAs and so get included in the suburbanization of the Alpine area (cf. Bätzing 2015). NPs and WNHSs, located more in inner-Alpine areas, present the lowest migration balances, suffer from the out-migration, esp. of younger people, into the national central areas, which is made up for by in-migration from abroad. However, differences between LPA municipalities by type of LPA are smaller than by country. The special demographic situation of WNHS municipalities seems to have to do with the fact that this type of LPA is only found in Italy and Switzerland (cf. Bender 2015).

The qualitative case studies (second Results section above) suggest that NPs are not seen by local stakeholders as detrimental for population development and particularly for in-migration. In Swiss NP, Hohe Tauern NP and Berchtesgaden NP the designation has had a positive effect on the tourism sector (Job et al. 2016; Getzner 2010; Backhaus et al. 2013), so that labour migration into NP municipalities can in part be attributed indirectly to the existence of the NPs. In the case of Stilfser Joch NP the tourism potential of the NP label is as yet largely untapped.

Second homes are either used irregularly as holiday homes or, in the context of a multi-local lifestyle, used regularly. The latter applies mainly to locals who have emigrated to agglomerations inside the Alps or on the Alpine rim and, for family reasons, visit their home area repeatedly. Quite often this leads to a permanent return after an absence for training or in older age. Amenity migrants in the narrow sense are the cohorts aged 50-74 years, who are familiar with the region from their travels. Purely amenity-oriented, permanent migration, however, plays a subordinate role in all case studies, which can be explained by the peripheral location of the regions in question. With increasing mobility, societal wealth and demographic change, amenity migration will become more important in Alpine regions in the future (Perlik 2006).

In terms of migration motives of the in-migrants in the municipalities we studied, economic motives (jobs, availability and price of housing), personal motives (family ties, ownership/inheritance of real estate, ties to the locality) and quality of life motives (attractive landscape, public services) seem relevant. The case studies reveal that NPs add value to the landscape quality of rural peripheral regions and in due course can attract tourists, second-home owners, amenity migrants and, indirectly, labour migrants, but this depends to a large extent on the local economic, political and spatial circumstances.

In total and with a critical look at the methods, the qualitative empirical approach proves to be advanta- geous and yields better explanatory patterns (at least of NPs, which were explored here in more detail) than a purely quantitative statistical analysis of data. In the case of Alpine LPAs this may be affected by the very small number of cases (except for the nature park type) and the highly divergent national and regional framework structures across the Alpine arc.

\section{Acknowledgements}

The authors are indebted to the interview partners in the LPAs and municipalities, the national statistics authorities of the six main Alpine countries, Austria, Germany, France, Italy, Slovenia and Switzerland, for providing the base data on population and migration statistics, to Andi Cziferszky and Nadine Houbé for their assistance with preparing LPA and statistical data, to Sigrun Kanitscheider for advice with the statistical data analysis, to Brigitte Scott for help with the translation, and to the reviewers and editors, who provided helpful comments on a previous draft of the manuscript.

\section{References}

Backhaus, N., C. Buser, M. Butticaz, D. Jorio \& M. Speich 2013. Wirtschaftliche Auswirkungen des Sommertourismus im UNESCO Biosphärenreservat Val Müstair Parc Naziunal. Schriftenreihe Humangeographie 27. Zürich. [In German]

Bätzing, W. 2015. Die Alpen. Geschichte und Zukunft einer europäischen Kulturlandschaft. 4. Auflage. München. [In German]

Bätzing, W. \& M. Perlik 1995. Tourismus und Regionalentwicklung in den Alpen 1870-1990. In: Luger, K. \& K. Inmann (eds.), Verreiste Berge - Kultur und Tourismus im Hochgebirge: 43-79. Innsbruck, Wien. [In German]

Becken, S. \& H. Job 2014. Protected areas in an era of global-local change. Journal of Sustainable Tourism 22 (4): 507-527.

Bender, O. 2012. Tourismus in peripheren Berggebieten - Heilsbringer oder falsche Hoffnung? In: Tourismusregion Mostviertel (ed.), Nachbaltigkeit in Szene gesetzt. 23-24. Wieselburg. [In German]

Bender, O. 2015. Study on immigration to and emigration from the Alps with respect to the 'new highlanders'. In: Permanent Secretariat of the Alpine Convention (ed.), Demographic Changes in the Alps. Report on the State of the Alps. Alpine Signals, Special Edition 5: 56-60. Innsbruck.

Bender, O. \& A. Borsdorf 2014. Neue Bewohner in den Alpen? Räumliche Mobilität und Multilokalität in Tirol. In: Chilla, T. (ed.), Leben in den Alpen: 15-30. Bern. [In German]

Bender, O. \& S. Kanitscheider 2012. New Immigration Into the European Alps: Emerging Research Issues. Mountain Research and Development 32 (2): 235-241.

Bender, O. \& S. Kanitscheider 2013. Amenity Migration in the Southern Andes and the Southern Eu- 
ropean Alps - a key factor for sustainable regional development? Mitteilungen der Österreichischen Geographischen Gesellschaft 155: 105-124. Vienna.

Bender, O., K.P. Schumacher \& D. Stein 2005. Measuring Seasonality in Central Europe's Tourism how and for what? In: Schrenk, M. (ed.), CORP 2005. Proceedings of $10^{\text {th }}$ Symposion on Information Technology in Urban- and Spatial Planning, February 22-25, Vienna University of Technology: 303-309. Vienna.

Bender, O., K.P. Schumacher \& D. Stein 2007. Landscape, seasonality, and tourism. A survey with examples from Central Europe. In: Palang, H., H. Sooväli \& A. Printsmann (eds.), Seasonal Landscapes 7: 181-214. Heidelberg, New York.

Borsdorf, A. 2009. Amenity Migration in Rural Mountain Areas. Editorial. Die Erde 140(3): 225-228.

Borsdorf, A. 2014. Second homes in Tyrol. Growth despite regulation. Journal of Alpine Research, Revue de Géographie Alpine. DOI: 10.4000/rga.2262

Butzmann, E. \& H. Job 2016. Developing a typology of sustainable protected area tourism products. Journal of Sustainable Tourism. DOI: 10.1080/09669582.2016.1206110

Cede, P., M. Beismann, J. Walder, R. Löffler \& E. Steinecke 2014. Neue Zuwanderung in die Alpen Der Osten ist anders. Mitteilungen der Österreichischen Geographischen Gesellschaft 156: 249-272. [In German]

Conradin, K. \& U. Wiesmann 2014. Does World Natural Heritage status trigger sustainable regional development efforts? eco.mont 6(2): 5-12.

del Negro, M. 2009. Schutzgebiete in Slowenien mit besonderer Berücksichtigung des Alpenraums. Bestandsaufnabme und Problematik. IGF-Forschungsberichte 3. Wien. IIn German]

Egli, H.-R. 2014. Siedlungs- und Bevölkerungsentwicklung in peripheren Gebieten des schweizerischen Alpenraums. In: Chilla, T. (ed.): Leben in den Alpen: 69-84. Bern.

Egner, H. \& M. Jungmeier (eds.) 2014. PARKS 3.0: Protected Areas for the next Society. Klagenfurt.

Fischer, W. \& J. Pizzera 2015. Österreich. In: Maier, J. (ed.), Sozialer und wirtschaftlicher Strukturwandel in Mitteleuropa 2004-2014. Ergebnisse der Tagung des Forschungssechsecks der Universitäten Bayreuth, Bratislava, Graz, Maribor, Pécs, Plzen. Arbeitsmaterialien zur Raumordnung und Raumplanung 283: 33-46. [In German]

Gebhard, H. 1990. Industrie im Alpenraum - alpine Wirtschaftsentwicklung zwischen Außenorientierung und endogenem Potential. Erdkundliches Wissen 99. Stuttgart. [In German]

Getzner, M. 2010. Impacts of protected areas on regional sustainable development: the case of the Hohe Tauern national park (Austria). International Journal of Sustainable Economy 2(4): 419-441.

Hammer, T. \& D. Siegrist 2015. Regional change management and collaborative regional governance as approaches tackling regional and global change in parks? In: Hammer, T., I. Mose, D. Siegrist \& N. Weixlbaumer (eds.), Parks of the Future: 85-101. München.

Hammer, T., I. Mose, D. Siegrist \& N. Weixlbaumer (eds.) 2015. Parks of the Future. München.

Hasslacher, P. 2016. Neue alpine Raumordnungsarchitektur dringend erforderlich. Innsbruck alpin 3: 37-41. [In German]

Job, H. 2005. Die Alpen als Destination. Eine Analyse in vier Dimensionen. Mitteilungen der Österreichischen Geographischen Gesellschaft 147: 113-138. Vienna. [In German]

Job, H. 2008. Die Destination Nationalpark Bayerischer Wald als regionaler Wirtschaftsfaktor. Grafenau. IIn German]

Job, H. 2017. Großschutzgebiete. In: ARL (ed.), Handwörterbuch der Stadt- und Raumentwicklung. $5^{\text {th }}$ Edition. Hannover (in print). [In German]

Job, H., S. Becken \& P. Sacher 2013. Wie viel Natur darf sein? Standort: Zeitschrift für angewandte Geographie 37(4): 204-210. [In German]

Job, H., M. Mayer \& F. Kraus 2014. Die beste Idee, die Bayern je hatte: der Alpenplan. Raumplanung mit Weitblick. GALA 23(4): 335-345. [In German]

Job, H., C. Merlin, D. Metzler, J. Schamel \& M. Woltering 2016. Regionalwirtschaftliche Effekte durch Naturtourismus. BfN-Skripten 431. Bonn. [In German]

Job, H., D. Metzler \& L. Vogt 2003. Inwertsetzung alpiner Nationalparks. Eine regionalwissenschaftliche Analyse des Tourismus im Alpenpark Berchtesgaden. Münchner Studien zur Sozial- und Wirtschaftsgeographie 43. München. [In German]

Krippendorf, J. 1975. Die Landschaftsfresser. Tourismus und Erholungslandschaft - Verderben oder Segen? Bern. [In German]

Kruskal, W.H. \& W.A. Wallis 1952. Use of ranks in one-criterion variance analysis. Journal of the American Statistical Association 47(260): 583-621.

Kupper, P. 2014. Wildnis schaffen. Eine transnationale Geschichte des Schweizerischen Nationalparks. Bern.

Lama, A.K. \& H. Job 2014. Protected areas and the road development: Sustainable development discourses in the Annapurna Conservation Area, Nepal. Erdkunde 68(4): 229-250.

Lange, S. 2005. Leben in Vielfalt. UNESCO-Biosphärenreservate als Modellregionen für ein Miteinander von Mensch und Natur. Wien. [In German]

Mayer, M. \& H. Job 2014a. The economics of protected areas - a European perspective. Zeitschrift für Wirtschaftsgeographie 58(2-3): 73-97

Mayer, M. \& H. Job 2014b. Die Bayerischen Alpen als Lebens- und Wirtschaftsraum zwischen Nutzungsund Schutzansprüchen. In: Chilla, T. (ed.), Leben in den Alpen: 31-48. Bern. [In German]

Mayring, P. 2002. Einführung in die qualitative Sozialforschung: Eine Anleitung zu qualitativem Denken. $5^{\text {th }}$ Edition. Weinheim. [In German]

Mose, I. 2004. Tourismus und Schutzgebietsplanung - Erfahrungen aus dem Nationalpark Hohe Tauern. Tourismus Journal 8(2): 211-222. [In German] 
Moss, L.A.G. (ed.) 2006. The Amenity Migrants: Seeking and Sustaining Mountains and Their Cultures. Wallingford.

Moss, L.A.G., R.S. Glorioso \& A. Krause (eds.) 2009. Understanding and Managing Amenity-led Migration in Mountain Regions. Proceedings of the conference in Banff, Alberta, Canada, May 15-19, 2008. Banff.

Perlik, M. 2006. The Specifics of Amenity-Migration in the European Alps. In: Moss, L.A.G. (ed.), The Amenity Migrants. Seeking and Sustaining Mountains and their Cultures: 215-232. Wallingford.

Perlik, M. 2011. Alpine gentrification. The mountain village as a metropolitan neighbourhood. New inhabitants between landscape adulation and positional good. Revue de Géographie Alpine 99(1): 1-15.

PSAC - Permanent Secretariat of the Alpine Convention (ed.) 2015. Demographic Changes in the Alps. Report on the state of the Alps. Alpine Convention. Alpine Signals - Special Edition 5. Innsbruck.

Pütz, M. \& H. Job 2016. Governance und Regionalentwicklung in Großschutzgebieten, diskutiert am Beispiel der Schweiz und Österreichs. Raumforschung und Raumordnung 74(6): in print. [In German]

Roth, C.E. 2016. Bevölkerungsentwicklung in Nationalparkgemeinden. Eine qualitative Studie in Nationalparks der Ostalpen. Master thesis. Würzburg. [In German]

Runte, A. 1977. The National Park Idea: Origins and Paradox of the American Experience. Journal of Forest History 21(2): 64-75.

Ruoss, E. 2016. Opportunities to leverage World Heritage Sites for local development in the Alps. eco.mont 8(1): 53-61.

Schumacher, H. \& H. Job 2013. Nationalparks in Deutschland - Analyse und Prognose. Natur und Landschaft 88 (7): 309-314. [In German]

Shafer, C.L. 2015. Cautionary thoughts on IUCN protected area management categories V-VI. Global Ecology and Conservation 3: 331-348.

Siegrist, D., S. Gessner \& L. Ketterer Bonnelame 2015. Naturnaher Tourismus. Qualitätsstandards für sanftes Reisen in den Alpen. Bern. [In German]

Sonderegger, R. 2014. Zweitwohnungen im Alpenraum. Bewertung des alpenweiten Bestandes und der Situation in der Schweiz in Bezug auf eine Nachbaltige Entwicklung. Saarbrücken. [In German]

Sonderegger, R. \& W. Bätzing 2012. Zweitwohnungen im Alpenraum. Journal of Alpine Research/Revue de Géographie Alpine. Hors-Série 2013. DOI : 10.4000/ rga.2517 [In German]

Steinicke, E., P. Cede \& R. Löffler 2012. In-migration as a new process in demographic problem areas of the Alps. Ghost towns vs. amenity settlements in the alpine border area between Italy and Slovenia. Erdkunde 66(4): 329-344.

Tappeiner, U., A. Borsdorf \& E. Tasser (eds.) 2008. Alpenatlas - Atlas des Alpes - Atlante delle Alpi-Atlas Alp-Mapping the Alps. Heidelberg.
UNESCO - United Nations Education, Scientific and Cultural Organisation 2015. Operational Guidelines for the Implementation of the World Heritage Convention. Paris.

\section{Data Sources}

Migration Statistics 2002-2011. Population Statistics 1/1/2002 (Statistik Austria)

Population Censuses 1999 and 2009 (INSEE, France)

Migration Statistics 2002-2011. Population Statistics, 1/1/2002 (DESTATIS and statistical offices of the Bundesländer, provided by Bayrisches LfStaD, Germany)

Migration Statistics 2002-2011. Population Statistics $1 / 1 / 2002$ (Istat, Italy)

Migration Statistics 2008-2012. Population Statistics 1/1/2008 (SI-STAT, Slovenia)

STATPOP 2010. Population Census 2001 (BfS, Switzerland)

\section{Authors}

\section{Oliver Bender}

is a senior scientist and head of the working group Man-Environment-Relations in Settlement Areas at the Institute for Interdisciplinary Mountain Research of the Austrian Academy of Science in Innsbruck. His research interests include landscape, regional and urban development. He acts as Austrian research coordinator in several COST Actions and as the Austrian member of the Board and of the Advisory Group of The Permanent European Conference for the Study of the $\mathrm{R} u$ ral Landscape (PECSRL). Austrian Academy of Sciences, Institute for Interdisciplinary Mountain Research, Technikerstr. 21a, 6020 Innsbruck, Austria. E-mail: oliver.bender@oeaw.ac.at

\section{Charlotte Elisabeth Roth}

studied geography at the Humboldt University in Berlin and at the Julius-Maximilian University of Würzburg. She is interested in regional development, governance and the management of protected areas. Institute for Geography und Geology, Human Geography, Julius-Maximilians-Universität Würzburg. Am Hubland, 97047 Würzburg, Germany. E-mail: charlotte.elisa.roth@gmail.com

\section{Hubert Job}

holds the chair for geography and regional science, Würzburg University, Germany. $\mathrm{He}$ is an elected member of the German Academy for Spatial Research and Planning and an appointed member of the German National Committee for the UNESCO programme on Man and the Biosphere. E-mail: hubert.job@uni-wuerzburg.de 